The new American diet is a family eating plan based on the five-year Family Heart study of 233 American families that was sponsored by the National Institute of Health. It is a high-carbohydrate low-fat diet that relies on gradual food substitutions.

No matter how good a diet is on paper, it is worthless if people won't use it. A classic example is the Pritikin approach. The compliance rate in the five-year study of the New American Diet was more than 80 percent, tremendous testimony to the program's effectiveness.

Instead of concentrating on fat, salt, or sugar, the New American Diet attempts to provide the best combination of all foods and nutrients based on the current state of knowledge. There is no caloriecounting, and people can eat until

\section{HAHNEMANN UNIVERSITY}

\section{DEPARTMENT} OF SURGERY

is sponsoring a

two and a half day

symposium:

\section{“CURRENT CONCEPTS IN}

\section{VASCULAR SURGERY"}

April 9, 10, 11, 1987

Adam's Mark Hotel

Philadelphia, Pennsylvania

For information and application:

Office for Continuing

Education

Hahnemann University

Broad and Vine Streets

Philadelphia, PA 19102

(215) 448-8267 full because the foods are lower in fat and higher in bulk than those in the typical diet. The diet promotes maximum weight loss in the form of fat rather than of water or muscle.

Included in the book is a quiz designed to assess the individual's current diet so trouble areas can be immediately identified. Helpful information on weight loss, lunches, snacking, eating out, holidays, and entertaining is provided. There is an extensive section directed toward educating the individual on the basics of nutrition. Critical to the diet's success are the 350 included recipes, which incorporate the basic principles outlined in the book.

It would be difficult to identify a finer source of dietary guidance for the busy professional. Routine "prescriptions" for the book would facilitate any coronary reduction, cholesterol lowering, or weight modification program.

It is likely that an inexpensive paperback edition will be published in the summer of 1987.

JOSEPH M. MERCOLA, D.O. Schaumburg, Illinois.

\section{Books received}

\section{New books received by the Andrew Taylor Still Memorial Library are ac- knowledged below. Those of greatest interest to readers will be reviewed later.}

Harrison's Principles of internal medicine. Edited by E. Braunwald, et al.; ed. 11, pp. 2118, with illus.; McGraw Hill Book Company, 1221 Avenue of the Americas, New York, 10020, 1987, \$85.00.

Surgical diseases of the pancreas. Edited by John M. Howard, George L. Jordan, Jr., and Howard A. Reber; pp. 958, with illus.; Lea \& Febiger, 600 Washington Square, Philadelphia 19106-9982, 1987, \$145.00.

Essentials of cardiac physical diagnosis. (A resource for students and house officers of general internal medicine and a reference for practicing cardiologists.) By
Jonathan Abrams; pp. 482, with illus.; Lea \& Febiger, 600 Washington Square, Philadelphia 19106-9982, 1987, \$34.50.

Genitourinary cancer management. (For urologists.) By Jean B. deKernion and David F. Paulson; pp. 297, with illus.; Lea \& Febiger, 600 Washington Square, Philadelphia 19106-4198, 1987, $\$ 50.00$.

Pigmented lesions of the skin: Clinicopathologic correlations. (For dermatologists and pathologists who want to improve their diagnostic skills.) By John C. Maize and A. Bernard Ackerman; pp. 328 , with illus.; Lea \& Febiger, 600 Washington Square, Philadelphia 19106-4198, $1987, \$ 89.50$.

Detection, prevention and management of urinary tract infections. By Calvin M. Kunin; ed. 4, pp. 447, with illus.; Lea \& Febiger, 600 Washington Square, Philadelphia 19106-4198, 1987, \$48.50.

Basic surgery. (Divided into 4 parts: General approach to surgery, physiology of surgical diseases, patient presentations, and a postlogue.) Edited by Hiram C. Polk, Jr., H. Harlan Stone, and Bernard Gardner; ed. 3, pp. 735, with illus.; Appleton-Century-Crofts, 25 Van Zant St., East Norwalk, CT 06855, 1987, $\$ 29.95$ (paper).

Diagnosing musculoskeletal problems: A practical guide. (Text provides conceptual tools, thinking strategies, and practical exercises.) By Frederick G. Lippert, III and Carol C. Teitz; pp. 115, with illus.; Williams and Wilkins, 428 East Preston Street, Baltimore, 21202, 1987, \$16.95 (paper).

Management of pediatric practice. (Explains how to start a practice and discusses good business procedures.) Edited by Edward J. Saltzman and Daniel W. Shea; pp. 138, with illus.; American Academy of Pediatrics, P.O. Box 927, 141 Northwest Point Road, Elk Grove Village, IL $60007,1986, \$ 30.00$ plus $\$ 2.50$ handling (paper).

Managing chronic disease. By C. Stewart Rogers, Jack D. McCue, and Peter Gal; pp. 439, with illus.; Medical Economics Books, Oradell, NJ 07649, 1987, \$29.95 (paper).

Fundamentals of skin biopsy. By June K. Robinson; pp. 124, with illus.; Year Book Medical Publishers, Inc., 35 East Wacker Drive, Chicago, 60601, 1986, \$24.95 (paper).

Anatomy: A regional atlas of the human 


\section{EXPANDING INTERNAL MEDICINE RESIDENCY PROGRAMS}

\section{FIRST, SECOND, THIRD YEAR POSITIONS AVAILABLE}

\section{BEGINNING JULY 1987}

OTHER RESIDENCY PROGRAMS
ANESTHESIA
ENT
GENERAL PRACTICE
GASTROENTEROLOGY
INTERNAL MEDICINE
OBSTETRICS
OPHTHALMOLOGY
ORTHOPEDICS
PATHOLOGY
PULMONARY
RADIOLOGY
SURGERY
UROLOGY
SUBSPECIALTY RESIDENCIES
GASTROENTEROLOGY
PULMONARY

Educational Programs

Daily Guest Lecturers

MONTHLY SEMINARS

MoRning Reports

Journal Clubs

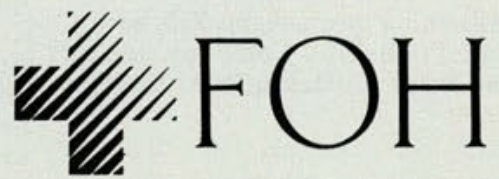

\footnotetext{
TO OBTAIN AN APPLICATION OR MORE INFORMATION ABOUT OUR PROGRAMS, CONTACT:

Flint Osteopathic Hospital Director of Medical Education 3921 BEECHER ROAD

FLint, MichigaN 48502

(313) $762-4707$
}

\section{A New Marketing Tool for Young Patients}

GOING TO THE

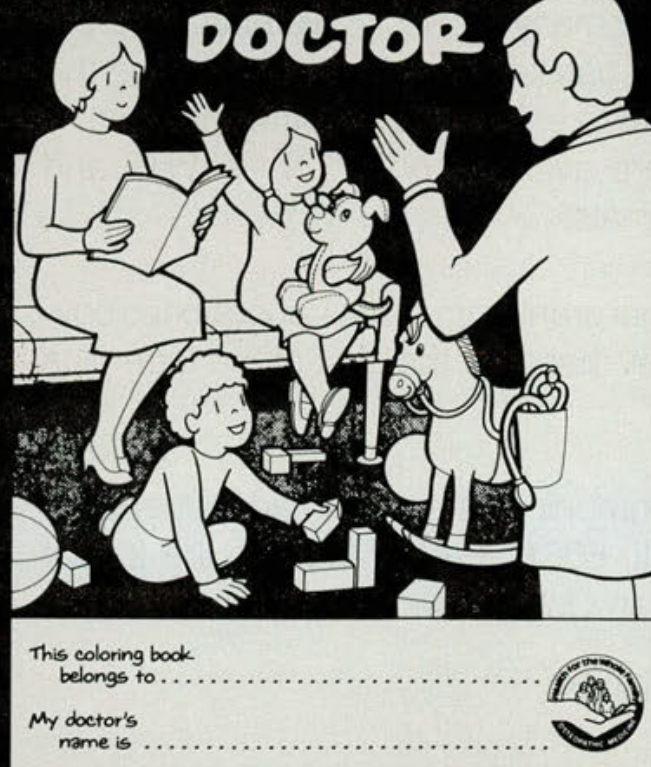

This eight page coloring book tells in simple terms what the D.O. does when giving a physical exam and presents in anxiety-allaying style some of his procedures. While waiting in the office, parents can talk it through, then take it home as a fun souvenir. Note that it can be personalized by adding your name on the cover.

Single review copies available at no charge. Additional copies $25 \phi$ each.

Order from:

Public Relations Department AMERICAN OSTEOPATHIC ASSOCIATION 212 East Ohio Street

Chicago, IL 60611 (1-800) 621-1773 
body. By Carmine D. Clemente; pp. 439, with illus.; Urban \& Schwarzenberg Medical Publishers, 7 East Redwood Street, Baltimore, MD 21202, 1987, \$42.50.

Orthopaedics for the medical student. Edited by Eric L. Radin; pp. 194, with illus.; J.B. Lippincott Company, East Washington Square, Philadelphia, 19105, 1986, $\$ 11.95$ (paper).

Biostatistics in clinical medicine. By Joseph A. Ingelfinger, et al.; ed. 2, pp. 339, with illus.; Macmillan Publishing Co., Inc., 866 Third Avenue, New York, 10022, 1987, \$29.95 (paper).

Occupational stress: Health and performance at work. Edited by Stewart G. Wolf, Jr., and Albert J. Finestone; pp. 255, with illus.; PSG Publishing Company, Inc., 545 Great Road, Littleton, MA 01460 , $1986, \$ 29.50$.

The coping capacity: On the nature of being mortal. By Avery D. Weisman; pp. 165; Human Sciences Press, Inc., 72 Fifth Avenue, New York, 10011, 1986, \$12.95 (paper).
About mourning: Support \& guidance for the bereaved. By Savine Gross Weizman and Phyllis Kamm; pp. 240; Human Sciences Press, Inc., 72 Fifth Avenue, New York, 10011-8004, 1987, \$16.95 (paper).

When a doctor hates a patient and other chapters in a young physician's life. By Richard E. Peschel and Enid Rhoades Peschel; pp. 189; University of California Press, 2120 Berkeley Way, Berkeley, CA $94720,1986, \$ 16.95$.

Medical education: Making the grade in cost containment. Edited by Russell D. Cunningham, Charles P. Friedman, and Bill Weaver; pp. 226; W.K. Kellogg Foundation, 400 North Avenue, Battle Creek, MI 49017-3398, 1986, free upon request (paper).

Evaluation of the hospital board and the chief executive officer. (How a board can establish standards and procedures for evaluating itself and its CEO-a practical guide, with checklists.) By Richard P. Moses; pp. 100; American Hospital Publishing, Inc., 211 East Chicago Avenue, Chicago, 60611, 1986, \$18.75 (AHA members $\$ 15.00$ ) (paper).
Hospital-based health promotion programs for children and youth. (An idea generator and guide for marketing services to a growing community.) By Ruth A. Behrens and Mary E. Longe; pp. 132; American Hospital Publishing, Inc., 211 East Chicago Avenue, Chicago, 60611, $1986, \$ 32.50$ (AHA members $\$ 26.00$ ) (paper).

Hospital-based medical office buildings. By Drexel Toland and Susan Strong; ed. 2, pp. 255, with illus.; American Hospital Publishing, Inc., 211 East Chicago Avenue, Chicago, 60611, 1986, $\$ 45.00$ (AHA members $\$ 36.00$ ) (paper).

Joint ventures for hospitals and physicians: Legal considerations. By Ross E. Stromberg and Carol R. Boman; pp. 280, with illus.; American Hospital Publishing, Inc., 211 East Chicago Avenue, Chicago, 60611, 1986, $\$ 55.00$ (AHA members $\$ 42.50)$ (paper).

Jewish values in bioethics. Edited by Rabbi Levi Meier; pp. 195; Human Sciences Press, Inc., 72 Fifth Avenue, New York, 10011-8004, 1986, $\$ 26.95$.

continued on page $155 / 113$

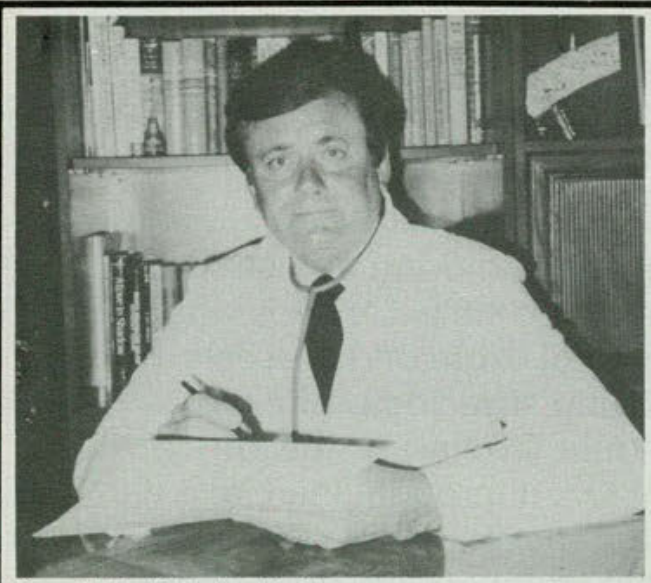

Donald E. Kotoske, D.O.

\section{AVAILABLE NOW!}

Videotape version of "Talk Show Tips for Os-
teopathic Physicians" by Donald E. Kotoske, D.O.

In response to many requests, we now have the popular audio cassette on videotape, adding the visual element to enhance the instructional material. Tapes are available on $1 / 2^{\prime \prime}$ or $3 / 4^{\prime \prime}$ VHS and Betamax formats.

An educational grant from Adria Laboratories covered all production costs so we are able to sell these for the cost of the tape plus handling and postage.

Orders should be addressed to: Director of Communications, American Osteopathic Association, 212 East Ohio Street, Chicago, IL 60611. Please indicate the format desired and make checks payable to: American Osteopathic Association. 


\section{The National Osteopathic Foundation Announces:}

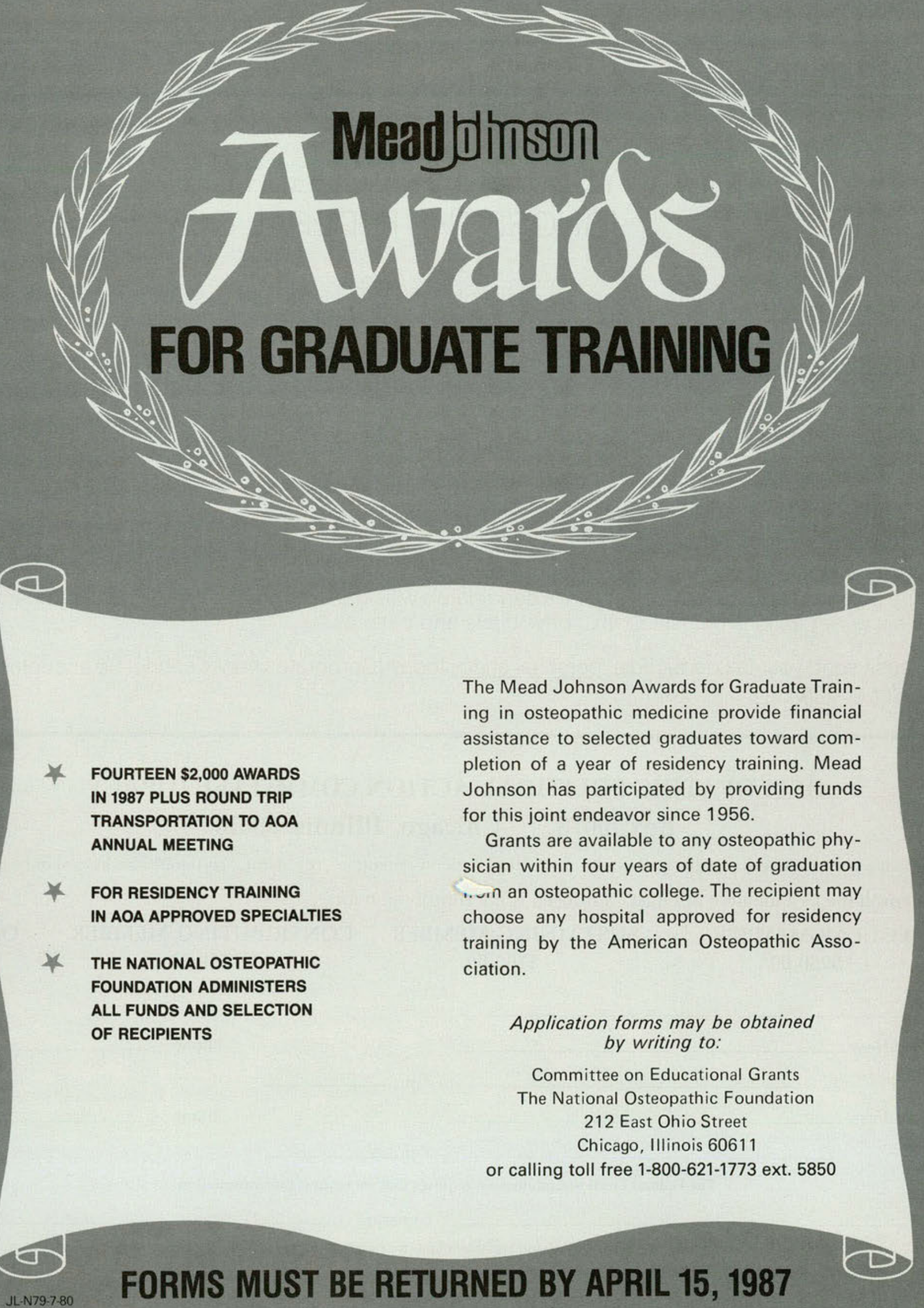




\section{YOU CAN NO LONGER AFFORD TO IGNORE THE FEDERAL GOVERNMENT}

Osteopathic Medicine has reached its status of high regard today because DOs have worked hard to gain and keep the right to provide the best health care available anywhere in the world

Our status is jeopardized by forces from within and without the government. Before the threats of today become tomorrow's reality - you can help.

OPAC, the Osteopathic Political Action Committee, is dedicated to the protection, preservation and advancement of the osteopathic profession.

Join the hundreds of DOs who already are committed to making OPAC an effective means of enhancing the profession's impact on Congress.

OPAC is non-partisan. It supports Republicans and Democrats, incumbents and challengers. One criterion is rated above all others: a candidate's willingness to consider the potential impact of his or her actions on osteopathic physicians and patients.

Please send your tax deductible, personal check today (Corporate checks cannot be accepted under Federal election laws).

\section{OSTEOPATHIC POLITICAL ACTION COMMITTEE (OPAC) Box 10078 Chicago, Illinois 60610}

Please make personal check payable to Osteopathic Political Action Committee (By statute, corporate checks cannot be accep Please enroll me as a member of OPAC. Enclosed is my contribution for:

REGULAR MEMBER

$\square \$ 250.00$

\section{SUSTAINING MEMBER}

$\square \$ 100.00$
CONTRIBUTING MEMBER

$\$ 50.00$

Other

Name

Home Address

Phone

$$
\text { Zip }
$$

Office Address

Phone

$$
\text { Zip }
$$

The Federal Election Commission requires that we request this information.

Date

Signature

A copy of our report is filed with the Federal Election Commission and is available for purchase from the Federal Election Commission, Wash, D.C., 
Nutritional assessment: Case study methods. (Essential procedures to assess nutritional status for dieticians and other health care professionals.) By Anne Dikovics; pp. 159, with illus;; George F. Stickley Company, 201 West Washington Square, Philadelphia, 19106, 1987, \$17.95 (paper).

Nutrition and your immune system. (For the layman.) By Carlson Wade; pp. 159; Keats Publishing, Inc., 27 Pine Street, P.O. Box 876, New Canaan, CT 06840, $1986, \$ 3.95$ (paper).

Are your dental fillings poisoning you? The hazards of mercury in your mouth. (For the layman.) By Guy S. Fasciana; pp. 224, with illus.; Keats Publishing, Inc., 27 Pine Street, P.O. Box 876, New Canaan, CT 06840, 1986, $\$ 12.95$ (paper).

The miracle nutrient coenzyme Q10. (For the layman.) By Emile G. Bliznakov and Gerald L. Hunt; pp. 240, with illus.; Bantam Books, 666 Fifth Avenue, New York, $10103,1987, \$ 4.50$ (paper).

A diabetic doctor looks at diabetes: His and yours. (For the layman.) By Peter A. Lodewick; pp. 232, with illus.; Bantam Books, 666 Fifth Avenue, New York, $10103,1987, \$ 3.95$ (paper).

\section{New members}

Alfano, Samuel L., PCOM '81; 4004 Birney Ave., Moosic, PA 18507

Brown, Robert R., UHS ' $80 ; 10460$ Mastin, Overland Park, KS 66212

Buckingham, John A., UHS ' 81 ; 10875 San Fernando Rd., Pacoima, CA 91331

Buckley, Timothy J., CCO ‘82; Apt. J, 2301 Freeport Rd., Sterling, IL 61081

Burgess, J.A., V, WVS '84; $215 \mathrm{~S}$. Louisiana Ave., Martinsburg, WV 25401

Capobianco, Anthony D., UNECOM '84; 264 Sea Cliff Ave., Sea Cliff, NY 11579

Casey, Robert J., CCO '76; 526 E. Dunlap, Phoenix, AZ 85020

Cleary, James P., PCO ‘66; 1380 Timberlane Dr., Lima, OH 45805
Gibson, Hanna Kaethe, KCOM ' 63 ; Box 20458, Portland, OR 97220-0458

Gorski, Dale J., COMP '84; Box 1268, 2776 Pacific Ave., Long Beach, CA 90801

Graves, Wayne D., KCOM ' $75 ; 2800$ Main, Kansas City, MO 64108

Horowitz, Norman P., COMP '84; 11432 Vanowen St., North Hollywood, CA 91605

Hubbard, Frank L., OCOMS ‘83; Box 69, Highway 181 South, Cabool, MO 65689

Kalamaris, John P., CCO ‘77; 5315 N. California Ave., Chicago, IL 60625

Kaplan, Robert J., PCO '78; No. 1, 8945 Ridge Ave., Philadelphia, PA 19128

Lloyd, S. Thomas, WVS ' $79 ; 760$ Stonecliff Dr., Akron, OH 44313

Lutz, Thomas W., UOMHS ' 68 ; 1993 Star Rt. 59, Kent, OH 44240

McCartney, Kevin M., UHS ' 82 ; 3231 Moller Rd., Indianapolis, IN 46224

McElroy, John B., COMP '84; 3578 Moultrie Ave., San Diego, CA 92117

Mellick, Gary A., Capt., OU ' $81 ; 1338$ Alderton Ln., Silver Spring, MD 20906

Mendelson, Sol, COMP ' $82 ; 6790$ Hellman, Alta Loma, CA 91701

Nevin-Woods, Christine, MSU ' 79 ; 1212D Hase Dr., Honolulu, HI 96819

Orland, Dennis, KCOM '64; 931 Hamburg Tpk., Wayne, NJ 07470

Pernicone, Joseph, MSU '79; 1560 Snyder Rd., East Lansing, MI 48823

Peterson, Gregory E., UOMHS '79; 1050 4th St., Bldg. 4, Des Moines, IA 50315

Raney, Mark S., KCOM '84; 7740 Normandy St., S.E., Olympia, WA 98501

Schauland, Marlin G.T., UOMHS ' $72 ; 5435$ Woodward, Detroit, MI 48202

Schwartz, Allan L., MSU ' $80 ; 17251$ Lee, Southfield, MI 48075

Shanklin, Stephen D., KCOM '72; 3304 E. Giddens, Tampa, FL 33610
Snell, Brent R., KCOM ' 82 ; 1100 E. Norris Dr., Ottawa, IL 61350

Strathie, Elizabeth M., PCO ‘ $40 ; 205$ S. Chancellor St., Newtown, PA 18940

Strode, W. Stevens, KCOM '73; Box 4520, Scottsdale, AZ 85261

Talarico, Joseph F., PCO ' $80 ; 151$ Sutcliffe Ln., Conshohocken, PA 19428

Vomastek, Roy L., KCOM '67; Box 38, McBain, MI 49657

Warmack, Bonnie M., UHS ' 68 ; 211 Glendale, Suite 216, Highland Park, MI 48203

Wilson, John A., UHS '63; Laughlin Medical Center, Box 661, Laughlin, NV 89029

Winner, Paul K., NYCOM '81; Apt. $11 \mathrm{E}, 1523$ Central Ave., Yonkers, NY 10710

Woods, Phillip H., Maj., TCOM '79; 1212D Hase Dr., No. A, Honolulu, HI 96819

\section{INTERNAL MEDICINE RESIDENCY}

Opening beginning July, 1987 in an expanding Internal Medicine program.

Well-covered subspecialty areas include:

- Gastroenterology

- Pulmonary Medicine/ Critical Care

- Cardiology

- Hematology/Oncology

- Neurology

- Rheumatology

- General Internal Medicine

Apply to:

Jonathan W. Karol, D.O.

Director of Medical Education

Osteopathic Hospital of

Maine, Inc.

335 Brighton Avenue

Portland, ME 04102

Phone: 207-772-3756 